DOI:

http://dx.doi.org/10.15448/1983-4012.2016.1.24298

\title{
THOREAU E CARLYLE: MORALIDADE, AUTOBIOGRAFIA E FICÇÃO LITERÁRIA
}

Thoureau and Carlyle: morality, autobiography and literary fiction

Eduardo Vicentini de Medeiros *

Resumo: $O$ uso extensivo do pronome da primeira pessoa do singular e o artifício retórico do exagero são duas marcas essenciais da prosa de Thomas Carlyle que podemos reidentificar nos textos de Henry David Thoreau. Essas características nos ajudam a explicar a relação interna entre autobiografia e ficcionalidade na concepção moral de Thoreau.

Palavras-chave: Henry David Thoureau. Thomas Carlyle. Moralidade. Ficcionalidade.

\begin{abstract}
The pervasive use of singular first person pronoun and the rhetorical artifice of exaggeration are two essential aspects of Thomas Carlyle's prose that we might reidentify examining Henry David Thoreau's literary outputs. Those characteristics help us to explain the internal relationship between autobiography and fictionality in Thoreau's moral overview.
\end{abstract}

Keywords: Henry David Thoureau. Thomas Carlyle. Morality. Fictionality.

* Doutor em Filosofia UFRGS/Cnpq. Pós-Doutorando PNPD Capes - Unisinos. Contato: donvicentini@gmail.com

\begin{tabular}{|c|c|l|l|l|l|}
\hline intuitio & $\begin{array}{c}\text { ISSN } \\
1983-4012\end{array}$ & Porto Alegre & Vol.9- $\mathrm{N}^{\mathrm{o}} .1$ & $\begin{array}{l}\text { Julho } \\
2016\end{array}$ & p.05-14 \\
\hline
\end{tabular}


O período do experimento de Henry David Thoreau às margens do lago Walden, entre julho de 1845 e setembro de 1847, foi um dos mais produtivos de sua curta vida como escritor: A Week on the Concord and Merrimack Rivers, Resistance to Civil Government e trechos importantes de seu Diário, que acabaram gerando os dois capítulos inicias de Walden, foram escritos nessa temporada. Durante o primeiro ano, Thoreau trabalhou em um longo artigo sobre a obra de Thomas Carlyle. Lido, em primeira versão, no Liceu de Concord em 1846 e publicado no ano seguinte, com o título Thomas Carlyle and his Works - nos servirá como bússola para identificar as contribuições para o pensamento de Thoreau daquele que "sozinho, depois da morte de Coleridge, manteve a promessa da Inglaterra."”

Após um intróito biográfico, Thoreau desenvolve a defesa do estilo literário de Carlyle das acusações de obscuridade e confusão que normalmente eram feitas aos autores de língua inglesa que se deixavam influenciar por maneirismos de extração germânica. Para Thoreau, a prosa de Carlyle representa um domínio exemplar da língua, e os elementos que encontramos em suas pirotecnias verbais têm origem nos momentos mais altivos de John Milton ou na dicção de Cromwell, que o próprio Carlyle ajudou a eternizar em Oliver Cromwell's Letters and Speeches. Thoreau valoriza o domínio da língua e fluidez da expressão de Carlyle acima de suas virtudes como crítico ou historiador.

Robert Sattelmeyer, em Thoreau's Reading, apresenta dois traços do estilo de Carlyle especialmente importantes na gestação e afirmação identitária da prosa thoreauviana, a saber, o uso literário da perspectiva da primeira pessoa do singular e a retórica do exagero:

During the second half of 1845 , while he was working on the Carlyle lecture, Thoreau was beginning to compose passages in the Journal, based in his life at the pond, of personal belief and social criticism that would form the kernel of 'Economy' and 'Where I Lived and What I Lived For' in Walden. Though he did not begin to write Walden itself until somewhat later, a large proportion of the material in the first draft can be found in the fragmentary Journal of 1845-1846. Many of these passages appear to be a response to and an imitation of the features of Carlyle's style that Thoreau found significant and praiseworthy, especially the adoption of a distinctive persona to unify and enliven diverse material, and the deliberate cultivation of a rhetoric of exaggeration. (...)Still, the rhetorical verve and distinctive - almost aggressive - insistence upon the first personness of the narrator in Walden may owe a great deal to Thoreau's immersion in Carlyle when the book was in its embryonic stage. ${ }^{2}$

O uso predominante da primeira pessoa do singular na prosa de Thoreau é um recurso estilístico que salta aos olhos, afirmado axiomaticamente nas primeiras páginas de Walden. ${ }^{3}$ Importante por ora manter em tela que a insistência na adoção de uma perspectiva de primeira pessoa para o narrador de

${ }^{1}$ THOREAU 1975, p.223

${ }^{2}$ SATTELMEYER 1988, p.39-40.Meus sublinhados.

3 "In most books, the I, or first person, is omitted; in this it will be retained; that, in respect to egotism, is the main difference. We commonly do not remember that it is, after all, always the first person that is speaking." THOREAU 1854/2004.

\begin{tabular}{|c|c|c|c|c|c|}
\hline intuitio & $\begin{array}{c}\text { ISSN } \\
1983-4012 \\
\end{array}$ & Porto Alegre & Vol. $9-\mathrm{N}^{\mathrm{o}} .1$ & $\begin{array}{l}\text { Julho } \\
2016 \\
\end{array}$ & p.05-14 \\
\hline
\end{tabular}


Walden, de acordo com a caracterização oferecida por Sattelmeyer, é, sobretudo, uma reação ao estilo literário de Carlyle.

A retórica do exagero aparece no artigo de Thoreau vinculado à sua leitura de um dos textos mais influentes de Carlyle, On Heroes, Hero-worship, and the Heroic in History:

No doubt, Carlyle has a propensity to exaggerate the heroic in history, that is, he creates you an ideal hero rather than another thing, he has most of that material. This we allow in all its senses, and in one narrower sense it is not so convenient. Yet what were history if he did not exaggerate it? How comes it that history never has to wait for facts, but for a man to write it? ${ }^{4}$

On Heroes apresenta seu tema em diferentes roupagens: o herói como divindade (Odin), como profeta (Maomé), como poeta (Dante, Shakespeare), como sacerdote (Lutero, Knox), como homem de letras (Johnson, Rousseau, Burns) e como rei (Cromwell, Napoleão). On Heroes foi responsável, braços dados com Hegel, por defender uma visão do desenvolvimento histórico dependente dos feitos de grandes homens. No entanto, o que mais impressionou Thoreau não foi a presença do herói como motor da história universal, e sim a possibilidade de reconhecer, através da biografia dos grandes homens, o heroísmo intrínseco a cada ser humano, transitando do elogio exacerbado da presença do herói na história, para o reconhecimento de que somos hiperbólicos em relação a nós mesmos:

Exaggeration! was ever any virtue attributed to a man without exaggeration? was ever any vice, without exaggeration? Do we not exaggerate ourselves to ourselves, or do we recognize ourselves for the actual men we are? Are we not all great men? ${ }^{5}$

Em seu Diário, nos primeiros dias do experimento em Walden, percebe-se dois movimentos retóricos surpreendentes suscitados pela leitura de On Heroes. O primeiro é a autoatribuição de heroísmo. O segundo, o reconhecimento de traços heroicos no homem simples, não apenas na sua pessoa, como nas figuras emblemáticas de um lenhador e dos trabalhadores anônimos da estrada de ferro. Em 07 de julho de 1845, três dias após o início de sua temporada às margens de Walden, Thoreau imagina-se em cenários homéricos:

I am glad to remember tonight,as I sit by my door, that I too am at least a remote descendant of that heroic race of men of whom there is tradition. I too sit here on the shore of my Ithaca, a fellow-wanderer and survivor of Ulysses. ${ }^{6}$

Após demandar imaginariamente sua descendência heroica, apenas sete dias se passam para que ele registre novos membros para sua tropa de heróis, o primeiro é Alek Therien, lenhador que trabalhava

\footnotetext{
${ }^{4}$ THOREAU 1975 p.264.

${ }^{5}$ THOREAU 1975, p.264

${ }^{6}$ THOREAU 1906, V 1 p. 363
}

\begin{tabular}{|c|c|c|c|c|c|}
\hline intuitio & $\begin{array}{c}\text { ISSN } \\
1983-4012\end{array}$ & Porto Alegre & Vol.9- $\mathrm{N}^{\circ} .1$ & $\begin{array}{l}\text { Julho } \\
2016\end{array}$ & p.05-14 \\
\hline
\end{tabular}


nas matas ao redor do lago e que fará sua reaparição, inominado, nos capítulos Reading e Visitors de Walden:

Who should come to my lodge just now but a true Homeric boor, one of those Paphlagonian men? Alek Therien, he called himself; a canadian now, a woodchopper, a post-maker (...) who made his last supper on a woodchuck which his dog caught. (...) The simple man. May the gods send him many woodchucks. ${ }^{7}$

O resto da imaginária tropa homérica é formada por cinco trabalhadores da ferrovia, representados como gigantes:

And earlier today came five Lestrigones, railroad men who take care of the road, some of them at least. They still represent the bodies of men, transmitting arms and legs and bowels downward from those remote days to more remote. They have some got a rude wisdom withal, thanks to their dear experience. ${ }^{8}$

Nada poderia ser mais avesso ao espírito elitista de Carlyle, que nos exige devoção incondicional aos grandes homens, do que essa reviravolta thoreauviana de apreço pelo homem simples. Jeffrey Cramer, no seu ensaio introdutório para a edição anotada de Walden, escreve sobre a diferença de atitude em relação ao heroísmo que Thoreau adota, na direção oposta a Carlyle e ao projeto similar de Emerson em Representative Men:

In 'Thomas Carlyle and His Works', Thoreau wrote about both Carlyle's On Heroes, Hero-Worship, and the Heroic in History and Emerson's Representative Men that neither represents "the Man of the Age, come to be called workingman." He continued, "It is obvious that none yet speaks to his condition, for the speaker is not yet in his condition." He understood, as he would write in 'Walking', that "the hero is commonly the simplest and obscurest of men." Consciously or not, Thoreau took up the challenge Carlyle wrote to Emerson on 29 August 1845: "I wish you would take an American hero, one whom you really love; and give us a History of him." Thoreau would redefine the heroic as he himself fulfilled the role of hero. By turning the experiment of life into a heroic task he was able to turn Walden from a philosophical tract of unattainable goals into a guide for the perplexed. He was able to make a representative man, not of the past, but of the present. ${ }^{9}$

É provável que Carlyle não ficasse satisfeito ao ver a condução de Thoreau para a sugestão feita na carta a Emerson. Uma biografia de Benjamin Franklin ou John Adams seria melhor recebida do que elogios a um lenhador canadense e simples trabalhadores braçais, imaginados em cenários homéricos nos Diários de um desconhecido escritor da Nova Inglaterra, que morava em uma cabana e plantava feijões.

\footnotetext{
${ }^{7}$ THOREAU 1906, V 1, p.365, 14/07/1845

${ }^{8}$ Idem.

${ }^{9}$ THOREAU 1854/2004, p.xxii.
}

\begin{tabular}{|c|c|c|c|c|c|}
\hline intuitio & $\begin{array}{c}\text { ISSN } \\
1983-4012\end{array}$ & Porto Alegre & Vol.9- $\mathrm{N}^{\circ} .1$ & $\begin{array}{l}\text { Julho } \\
2016\end{array}$ & p.05-14 \\
\hline
\end{tabular}


"Não exageramos nós mesmos para nós mesmos?" Movido pelo transbordamento do gênio romântico, ou pela reflexão sobre os fenômenos mais corriqueiros do autoengrandecimento, autoengano e da confabulação, Thoreau constata que não nos reconhecemos pelo homem que de fato somos. Aceitar a retórica do exagero nos exercícios autobiográficos é uma forma de superar a timidez do homem apologético, na direção da afirmação autônoma da self-reliance emersoniana ${ }^{10}$, tão mal digerida pelo senso comum moral e vista apenas como arroubos de indevida petulância. O mesmo se passa aqui com a sugestão de que o exagero de si mesmo é uma constante psicológica da vida moral. Exagerar a si mesmo é uma das formas de proclamar a autoinvenção, é reconhecer que a identidade pessoal não é construída apenas na conectividade da memória, como tradicionalmente em Locke, mas também pelo uso da imaginação. Thoreau admite a importância da imaginação na identidade pessoal e representa a plasticidade e elasticidade do self utilizando símiles para impermanência e mutabilidade, acatando, por exemplo, a singular tese emersoniana, segundo a qual, a perfeição do caráter funcionaria como um ideal nunca de fato alcançado. Os sucessivos estágios do sujeito moral, cada estágio superando o anterior e sendo superado por um próximo, seriam marcados por uma transitoriedade em movimento perpétuo.

À transitoriedade do self na psicologia moral emersoniana, Thoreau adiciona um novo componente, que podemos chamar de 'cumulatividade'. Quando lemos um livro, percorremos as páginas transitando por diferentes estágios, de modo análogo como transitamos por diferentes identidades em um processo perfeccionista. As páginas que já foram lidas continuam lá, de fato são estágios pelos quais já passamos. Mas, de forma alguma, são páginas viradas, esquecidas:

The life in us is like the water in the river; it may rise this year higher than ever it was know to before and flood the uplands - even this may be the eventful year and drown out all our muskrats.

There [are] as many strata at different levels of life as there leaves in a book. Most men probably have lived in two or three. When on the higher levels we can remember the lower levels, but when on the lower we cannot remember the higher.

My imagination, my love and reverence and admiration, my sense of the miraculous, is not so excited by any event as by the remembrance of my youth. ${ }^{11}$

Uso o conceito de "cumulatividade" para designar uma operação diferente da memória. Posso lembrar do que já fiz, do que já fui, mas "cumulatividade" é continuar sendo o que já fui, é não renegar o passado como algo que deixei de lado, é ter a imaginação despertada pelos eventos e personalidades pretéritas, reverenciando ou criticando-os na proporção devida.

\footnotetext{
${ }^{10}$ Self-Reliance, texto fundamental de Ralph Waldo Emerson, sem o qual é impossível compreender o ethos do Transcendentalismo Americano, publicado em Essays- First Series (1841).

11 THOREAU 1906, V 2 p. 33, 09/06/1850.
}

\begin{tabular}{|c|c|c|c|c|c|}
\hline intuitio & $\begin{array}{c}\text { ISSN } \\
1983-4012\end{array}$ & Porto Alegre & Vol.9- No.1 & $\begin{array}{c}\text { Julho } \\
2016\end{array}$ & p.05-14 \\
\hline
\end{tabular}


Em Walden a passagem acima dos Diários é reutilizada na Conclusão, com um adendo importante:

The life in us is like the water in the river. It may rise this year higher than man has ever known it, and flood the parched uplands; even this may be the eventful year, which will drown out all our muskrats. It was not always dry land where we dwell. ${ }^{12}$

É possível que tenhamos escolhido habitar terras antes inundadas pelos próprios excessos da imaginação. $\mathrm{O}$ exagero sobre si mesmo, apesar de ser um fenômeno natural e esperado, deve e pode ser mantido sob controle. A matéria prima oferecida pela imaginação na criação de uma identidade pode e deve ser trabalhada com critério: "When one man has reduced a fact of the imagination to be a fact to his understanding, I foresee that all men at length establish their lives on that basis."13

A moralidade, prismada no romantismo thoreauviano, é a tentativa de domesticação do gênio pelo caráter, pelo menos essa é a aposta de seu Diário em 02 de março de 1842: "Character is Genius settled. It can maintain itself against the world, and if it relapses it repents. It is a dog set to watch the property of Genius. Genius, strictly speaking, is not responsible, for it is not moral." 14

O cuidado de Thoreau na escolha das palavras beira o cirúrgico, e o emprego do verbo "settle" na expressão "character is Genius settled" é prova disso. Todo espectro semântico do verbo está presente. Assentar, resolver, reconciliar, retificar, colocar em ordem, estabelecer, ocupar, acalmar, mas, acima de todos os diferentes sentidos e agrupando-os metaforicamente: habitar, estabelecer-se em um lugar. O caráter constrói a morada do gênio, o caráter oferece habitação ao gênio.

Converter um fato da imaginação em um fato do entendimento é outro modo de dizer a mesma coisa, desde que estejamos dispostos a reconhecer a função do entendimento na construção do caráter.

O caráter é construído colocando a vida individual em perspectiva ${ }^{15}$ : examinando, comparando e sopesando as diferentes folhas deste livro onde a vida está escrita. No caso de Thoreau, que depositou mais de dois milhões de palavras em seus Diários, dizer que a construção do caráter é um exercício autobiográfico de escrita e leitura séria é uma obviedade. Menos óbvio é afirmar que, ao transformar seu Diário em Walden, o ponto focal da narrativa não é mais Henry David Thoreau, mas um personagem ficcional como Aquiles na Ilíada, Bloom em Ulysses, Captain Ahab em Moby-Dick ou Diogenes Teufelsdröckh em Sartor Resartus.

Nas primeiras palavras de Walden lemos a exigência, feita a todo escritor, que dê um "relato simples e sincero de sua vida" e criamos a expectativa de que Walden será um relato deste tipo sobre

${ }^{12}$ THOREAU 1854/2004, p. 324. Meu sublinhado.

${ }^{13}$ IDEM, p. 11

${ }^{14}$ THOREAU 1906,V1, p. 324.

15 "It would be well if we saw ourselves as in perspective always, impressed with distinct outline on the sky, side by side with the shrubs on the river's brim." THOREAU 1906,V 1, p. 140, 15/06/1840.

\begin{tabular}{|c|c|c|c|c|c|}
\hline intuitio & $\begin{array}{c}\text { ISSN } \\
1983-4012 \\
\end{array}$ & Porto Alegre & Vol. $9-\mathrm{N}^{\mathrm{o}} .1$ & $\begin{array}{l}\text { Julho } \\
2016 \\
\end{array}$ & p.05-14 \\
\hline
\end{tabular}


Henry David Thoreau, mas o "eu" que narra em Walden ganha sucessivas características ficcionais que o distanciam do Henry David Thoreau histórico. E o modo como leio Walden pressupõe que este estranhamento não é acidental e sim parte importante da compreensão da obra e, por consequência, elemento fundamental no desenvolvimento do pensamento moral de Thoreau.

Qual a origem dessa peculiar combinação de autobiografia e ficcionalidade? Minha sugestão é olhar, novamente, para Thomas Carlyle and his Works: "Sartor Resartus is, perhaps, the sunniest and most philosophical, as it is the most autobiographical of his works, in which he drew most largely on the experience of his youth."16

Sartor Resartus não é obra de fácil resenha, mas é preciso identificar alguns elementos da narrativa para explicar por que Thoreau a considera uma obra autobiográfica. Sartor Resartus apresenta, na figura de um Editor - cujo nome não é declarado - uma tentativa de resenha de "Die Kleider, ihr Werden und Wirken" (Roupas, sua Origem e Influência) do filósofo alemão Diogenes Teufelsdröckh. O Editor, no esforço de compreender obra tão singular, recebe, com a ajuda de Hofrath Heuschrecke (um conterrâneo de Teufelsdröckh), um conjunto de documentos biográficos sobre o filósofo que não passa de um amontoado caótico de papéis:

(...)Six considerable PAPER-BAGS, carefully sealed, and marked successively, in gild China-ink, with the symbols of the Six southern Zodiacal Signs, beginning at Libra; in the inside of which sealed Bags lie miscellanious masses of Sheets, and oftener Shreds and Snips, written in Professor Teufelsdröckh's scarce legible cursiv-schrift; and treating of all imaginable things under the Zodiac and above it, but of his own personal history only at rare intervals, and then in the most enigmatic manner. ${ }^{17}$.

O livro segundo de Sartor trata da biografia de Teufelsdröckh por meio do arranjo que foi possível ao Editor fazer dos escritos recebidos nas seis sacolas de papel. O que o Editor faz, portanto, é uma colagem dos textos escritos por Teufelsdröckh e apresenta-os como uma autobiografia. A sugestão de Thoreau é que seria possível inferir elementos da biografia do próprio Carlyle a partir da reconstrução feita pelo Editor (personagem que podemos pensar como um alter-ego de Carlyle) da vida de Teufelsdröckh. Emblematicamente, portanto, Sartor Resartus oferece uma apresentação literária da conexão entre autobiografia e ficção.

Contudo, como explicar que Thoreau considere Sartor não apenas como a obra mais autobiográfica, mas a mais filosófica de Carlyle? A resposta direta é atentar para o conteúdo do que é dito em Sartor. Afinal de contas, o livro é uma resenha de outro livro que trata da filosofia das roupas, de uma Lebensphilosophie, que só será compreendida quando contrastada com o pano de fundo da vida de seu autor, como lembra Heuschrecke em uma carta ao Editor:

\footnotetext{
${ }^{16}$ THOREAU 1975, p.254.

${ }^{17}$ CARLYLE 1834/1956, p.58
}

\begin{tabular}{|c|c|c|c|c|c|}
\hline intuitio & $\begin{array}{c}\text { ISSN } \\
1983-4012\end{array}$ & Porto Alegre & Vol.9- $\mathrm{N}^{\circ} .1$ & $\begin{array}{l}\text { Julho } \\
2016\end{array}$ & p.05-14 \\
\hline
\end{tabular}


Hofrath Heuschrecke, in a too long-winded Letter,(...) proceeds to remind us of what we know already: that however it may be with Metaphysics, and other abstract Science originating in the Head (Verstand) alone, no Life-Philosophy (Lebensphilosophie), such as this of Clothes pretends to be, which originates equally in the Character (Gemüth), and equally speaks thereto, can attain its significance till the Character itself is know and seen; ' till the Author's View of the World (Weltansicht), and how he actively and passively came by such view, are clear: in short till a Biography of him has been philosophico-poetically written and philosophico-poetically read. ${ }^{18}$

Uma resposta mais longa, para qual confesso que me falta fôlego e os meios para percorrer, passaria por um acerto de contas entre a filosofia de Fichte e o gênio literário de Carlyle. Resposta que é sugerida em um artigo de Kit Andrews, onde teses de German Idealism - The Struggle against Subjectvism, 1781 - 1801, de Frederick Beiser, são utilizadas para este fim:

Carlyle scholarship has carefully documented, analyzed, and argued over the importance of Fichte's philosophy for Carlyle's thought. Beiser's revaluation of Fichte's influence on German literature has not yet been considered, though, as a way to understand Fichte's corresponding influence on Carlyle's quirky blend of biographical fiction and German Idealism in Sartor Resartus (1833-34). This article seeks to include Carlyle as a member of that set of post-Fichtean writers, for whom, as Beiser explains, "drama and the novel" became "the only proper medium to explore and resolve philosophical problems" (German Idealism,379). Like the German writers (Novalis, Holderlin, Friedrich Schlegel, and Jean Paul Richter) who closely read, and in some cases attended, Fichte's 1794 lectures collected as the first Wissenschaftslehre (Science of Knowledge), Carlyle found in the representation of particular lives a unique, and to some extent necessary, literary form through which to further develop and attempt to resolve the philosophical tensions that animate Fichte's thought. ${ }^{19}$

Walden também oferece uma Lebensphilosophie. Economia pode ser lido como um tratado sobre a filosofia das roupas, do abrigo, da alimentação e do combustível, em resumo, um tratado sobre como manter-se aquecido. Economia fala de atividades que eu realizo. Ser filósofo é resolver os problemas da vida na prática: "Philosophia practica est eruditionis meta, philosophy practiced is the goal of learning" 20

Parte do que está sugerido na revalorização heróica do 'the Man of the Age, come to be called working-man" é o elogio do caráter prático, da filosofia orientada para os desafios do prosaico, do corriqueiro. Nada mais prosaico, nada mais comum do que a necessidade de manter-se aquecido e o filósofo é aquele que sabe como lidar da melhor maneira com as tarefas do diário. Não é a toa que Thoreau elogia a intepretação que Carlyle oferece para o lema délfico: "The before impossible precept,

${ }^{18}$ CARLYLE 1834/1956, p.56

${ }^{19}$ ANDREWS 2012, p.722. Meu sublinhado.

${ }^{20}$ THOREAU 1975, p. 249

\begin{tabular}{|c|c|c|c|c|c|}
\hline intuitio & $\begin{array}{c}\text { ISSN } \\
1983-4012\end{array}$ & Porto Alegre & Vol.9- $\mathrm{N}^{\circ} .1$ & $\begin{array}{l}\text { Julho } \\
2016\end{array}$ & p.05-14 \\
\hline
\end{tabular}


'know thyself', he translates into the partially possible one, 'know what thou canst work at' "'21 A mesma ideia aparece nos Diários e retrabalhada em Walden:

Next to us is not the workman whom we have hired, but ever the workman whose work we are. He is at work, not in my backyard, but inconceivably nearer than that. ${ }^{22}$

Next to us is not the workman whom we have hired, with whom we love so well to talk, but the workman whose work we are."23

Para usar uma expressão que Gilbert Ryle colocou em circulação, autoconhecimento é uma variedade de 'saber como'. Ou, para colocar nos termos de Carlyle: "A certain inarticulate Selfconsciousness dwells dimly in us; which only our Works can render articulate and discernible. Our Works are the mirror wherein the spirit first see its natural lineaments" 24

Considerando o que foi exposto, não é apressado concluir que o uso literário da primeira pessoa em uma retórica do exagero mapeia duas rotas paralelas no desenvolvimento do pensamento moral de Thoreau. A primeira é a atribuição de traços heroicos ao homem simples, ao Man of the Age, representado em Walden como uma ficção autobiográfica. A segunda passa pelo reconhecimento de que a retórica do exagero também é uma constante do exercício autobiográfico, o que explica sua ficcionalidade. As conexões entre ficção e autobiografia, e entre autobiografia e moralidade, ganham relevo se lembrarmos que Carlyle descreve a Lebensphilosophie de Teufelsdröckh como produto não só do entendimento, mas do caráter, que, em última instância, é o substrato de todas as habilidades e talentos que coloco em funcionamento nas rotinas do diário. Lição que é explicitamente reconhecida por Thoreau:

Our true character silently underlies all our words and actions, as the granite underlies the other strata. Its steady pulse does not cease for any deed of yours, as the sap is still ascending in the stalk of the fairest flower." 25

\section{Referências}

ANDREWS, Kit. 2012. Fichte, Carlyle and the British Literary Reception of German Idealism. Literature Compass 9/11, 721-732.

BEISER, Frederick C. 2002. German Idealism - The Struggle against Subjectivism, 1781 - 1801. Harvard University Press.

CARLYLE, Thomas. 1834/1956. Sartor Resartus. Londres. J.M. Dent.

SATTELMEYER, Robert. 1988. Thoreau's Reading - A Study in Intellectual History with Bibliographical Catalogue. Princeton: Princeton University Press.

${ }^{21}$ THOREAU 1975, p.254

${ }^{22}$ THOREAU 1906, V 1, p. 364, 07/07/1845.

${ }^{23}$ THOREAU 1854/2004, p. 130

${ }^{24}$ CARLYLE 1834/1956 p.124.

${ }^{25}$ THOREAU 1906, V 1, p. 257, 03/05/1841.

\begin{tabular}{|c|c|l|l|l|l|}
\hline intuitio & $\begin{array}{c}\text { ISSN } \\
1983-4012\end{array}$ & Porto Alegre & Vol.9- $\mathrm{N}^{\circ} .1$ & $\begin{array}{l}\text { Julho } \\
2016\end{array}$ & p.05-14 \\
\hline
\end{tabular}


THOREAU, Henry David. 1975. Early Essays and Miscellanies. Princeton University Press.

THOREAU, Henry David. 1906. The Journal of Henry David Thoreau, 14 volumes, editado por Bradford Torrey e Francis H. Allen. Boston: Houghton Mifflin.

THOREAU, Henry David. 1854 / 2004. Walden - A Fully Annotated Edition. Editado por Jeffrey Cramer. Yale University Press.

Recebido em: 15/06/2016

Aprovado para a publicação em: 30/06/2016

\begin{tabular}{|c|c|c|c|c|c|}
\hline intuitio & $\begin{array}{c}\text { ISSN } \\
1983-4012\end{array}$ & Porto Alegre & Vol.9- $\mathrm{N}^{\mathrm{o}} .1$ & $\begin{array}{l}\text { Julho } \\
2016\end{array}$ & p.05-14 \\
\hline
\end{tabular}

